\title{
O Profissionalismo e a Formação Médica
}

\section{Professionalism and Medical Training}

Sergio $\operatorname{Rego} O^{I}$

A palavra "profissional" está associada a um conceito muito importante em nosso quotidiano e para o qual gostaríamos de trazer sua atenção neste final de ano. De fato, é fácil associar ideias ao conceito de profissional quando, por exemplo, precisamos de um eletricista para nossa casa ou de um mecânico para o nosso carro. Queremos contratar alguém em quem possamos confiar e que detenha um conhecimento especializado que atenda às nossas necessidades. Infelizmente, nem sempre é fácil achar um eletricista ou mecânico que atendam às nossas expectativas. Uma das razões é que, não sendo uma ocupação plenamente regulamentada, não temos garantias de que os eletricistas e mecânicos com quem lidaremos tenham a formação e experiência necessárias e nem a honestidade que se espera daqueles a quem gostaríamos de nos referir como profissionais. Tentamos aumentar nossa chance de ter nossas expectativas atendidas recorrendo a estabelecimentos comerciais que possuem outras responsabilidades adicionais com seus clientes, entre as quais a de ter verificado as qualificações e habilidades desses trabalhadores. Mas, saindo deste exemplo introdutório, pensemos em sua relação com as profissões de fato e de direito e seus atores - os profissionais.

Os sociólogos costumam identificar algumas profissões como ícones da profissionalização, e a medicina, a engenharia e a advocacia estão entre os exemplos mais costumeiros e tradicionais. Podemos dizer, inclusive, que o modelo de profissional que extrapolamos para trabalhadores em geral tem sua origem nas características práticas que marcam essas ocupações altamente especializadas. Essas profissões, entre outras, requerem um longo e complexo processo de formação e se conformaram com a prática do que se convencionou chamar de "ideal de serviço", ou seja, o compromisso de colocar os interesses dos clientes à frente dos próprios interesses. Competência técnica, honestidade, compromisso de falar a verdade estão entre essas características que acabam sendo projetadas para as demais ocupações quando pensamos em nossas expectativas sobre como devem ser os profissionais que queremos contratar.

O que conformava o profissionalismo nos séculos XIX e XX sofreu as inevitáveis mudanças resultantes das próprias transformações sociais e da forma como as profissões se relacionavam com o aparelho de Estado. No final do século XX, essas mudanças já eram discutidas como sinais de que um processo de desprofissionalização estaria em curso. Na época, eu já entendia esse processo como uma reprofissionalização, ou seja, uma transformação nas bases do profissionalismo, com as mudanças nas relações econômicas. Hoje, devemos nos perguntar não apenas sobre quais são os valores, regras e normas da profissão médica para o século XXI, mas também sobre o que fazemos, como docentes e cidadãos, para formá-los.

Lamentavelmente, é cada vez mais frequente acompanharmos na mídia nacional episódios em que ocorreram faltas lamentáveis de profissionalismo entre colegas. As mais recentes estiveram relacionadas a ausência por motivo não razoável e nem justificável a plantões, sendo o caso de maior repercussão a ausência de um neurocirurgião a um plantão no Hospital Salgado Filho, no Rio de Janeiro. Ainda que o caso não deva ser discutido sem conside- 
rar os problemas de gestão da Secretaria de Saúde do Estado e da própria chefia de plantão e que as informações veiculadas pela mídia não sejam, necessariamente, acuradas, o fato é que são totalmente inaceitáveis as justificativas até agora divulgadas estar demissionário e/ou a SES não cumprir resolução do Cremerj segundo a qual são necessários dois neurocirurgiões por plantão. E são inaceitáveis também frente ao novo Código de Ética Médica, que prevê, em seu capítulo $3^{\circ}$, artigo $9^{\circ}$, que é vedado ao médico "deixar de comparecer a plantão em horário preestabelecido ou abandoná-lo sem a presença de substituto, salvo por justo impedimento".

Mas o profissionalismo não se ensina com a mera apresentação do Código de Ética, nem muito menos se esgota em seu conteúdo. É preciso que docentes, estudantes e profissionais tenham clareza de que o profissionalismo é a base do contrato social que nos legitima como profissão em nossa sociedade. Assim, a compreensão sobre o que é o profissionalismo na medicina e o que devemos fazer no processo de formação para assegurar que estamos formando futuros profissionais assume papel crucial. Todos sabemos que expertise técnica é indispensável, mas que também não é a única dimensão essencial na formação.

No início deste século, três organizações de medicina interna, American Board of Internal Medicine Foundation, American College of Physicians Foundation e a European Federation of Internal Medicine divulgaram um documento no qual listam o que reconheceram como os "Princípios Fundamentais do Profissionalismo Médico para o Século XXI"1:

a) Princípio da primazia do bem-estar do paciente - “baseado na dedicação para servir ao interesse do paciente" (p.520);

b) Princípio da autonomia do paciente - “[...] médicos devem ser honestos com seus pacientes e empoderá-los para tomarem decisões esclarecidas sobre seus tratamentos [...]"(p.520);

c) Princípio da justiça social - "a profissão médica deve promover a justiça no sistema de saúde, incluindo a justa distribuição dos recursos de cuidado à saúde $[\ldots]^{\prime \prime}($ p.520).
Esse mesmo documento apresenta o que identificam como as "Responsabilidades Profissionais":

a) compromisso com a competência;

b) compromisso com a honestidade com os pacientes;

c) compromisso com a confidencialidade com os pacientes;

d) compromisso de manter relações apropriadas com os pacientes;

e) compromisso de melhorar a qualidade do cuidado;

f) compromisso de melhorar o acesso ao cuidado em saúde;

g) compromisso com a distribuição justa dos recursos finitos;

h) compromisso com o conhecimento científico;

i) compromisso de manter a confiança com o manejo apropriado dos conflitos de interesse;

j) compromisso com as responsabilidades profissionais.

Resta a nós nos perguntar: temos clareza de quais são os valores e compromissos essenciais da profissão médica no Brasil? Estamos usando as melhores estratégias, métodos e técnicas de ensino para assegurar a formação de profissionais comprometidos com seu tempo? Esse desafio é nosso.

\section{REFERENCIA}

1. Brennan T, Blank L, Cohen J, Kimball H, Smeler N, Copeland $\mathrm{R}$, et al. Medical professionalism in the new millennium: a physicians'charter. Lancet [periodico na internet]. 2002 [acessado em dez. 2013];359(9305):520-2. Disponível em: http://www.sciencedirect.com/science/journal/01406736/359/9305

\section{ENDEREÇO PARA CORRESPONDÊNCIA}

Rua Leopoldo Bulhões, 1480 - sala 919

Manguinhos - Rio de Janeiro

21041-210 RJ

rego@ensp.fiocruz.br 